\title{
Awareness of Adolescent Girls about Basic Nutritional Needs during Pregnancy
}

\author{
Ola Mohamed Mousa \& Naglaa Saad Abd El-Aty.
}

Lecturer of Obstetrics and Gynecology Nursing, Faculty of Nursing Minia University, Egypt

Lecturer of Community Health Nursing, Faculty of Nursing, Assiut University, Egypt

\begin{abstract}
The present study Aimed To determine the awareness of adolescents towards basic nutritional needs during pregnancy. The study is a Descriptive Cross-Sectional study Conducted among two maternal and child health centers El Minia City. A convenient Sample composed of 120 adolescent girls. Tools of the study comprised of interview questionnaire (awareness assessment sheet) which separated into three parts, the first part was about (socio-demographic characteristics, nutritional needs and adolescent awareness of basic nutritional needs). Results: the present study Revealed that there is a significant difference on the level of knowledge of the respondents from the rural and urban areas with regards on the following items: the nutrients that should be more of them for pregnant, and the importance of folic acid component for pregnant and about of half of rural adolescents were not aware about basic nutritional needs during pregnancy. Conclusion: the present study concluded that there is a significant relationship between the level of knowledge and the following socio-demographic characteristics: age, level of education, birth order, and mother's educational attainment, also there is significant relationship between the level of awareness and the following socio-demographic characteristics: age, level of education. It was recommended that: The school education program for school girls about dietary education and nutritional needs at this age can improve the overall health and nutritional knowledge and status of adolescents.
\end{abstract}

Keywords. Basic nutritional needs, Pregnancy, Adolescent, Awareness, Food \& Nutrition.

\section{Introduction}

Adolescents, defined as aged 10-19 years (United Nations Children's Fund, 2013). Adolescents and young people represent the future of every society. Better education and public health measures can be hugely beneficial to their health and development Amanifesto for the world we want. Lancet (2012). Adolescents are tomorrow's adult population. In 2009, there were 1.2 billion adolescents aged 10-19 in the world, forming 18 per cent of world population. Adolescent numbers have more than doubled since 1950. The vast majority of adolescents -88 per cent - live in developing countries. The least developed countries are home to roughly 1 in every 6 adolescents. (United Nations, Department of Economic and Social Affairs, 2010).

Adolescent girls are backbone of healthy and progressive family and thus future builders of positive health of community. To attain healthy reproductive outcome and efficient physical activity nutritional status of adolescent girl is valuable. (Sheloj et al., 2014). In recent years, importance of health counseling for adolescents has been appreciated but there are no large-scale community based studies to assess awareness about basic nutritional needs in Egyptian adolescent girls. In Egypt, problems are more difficult and complicated because of marked socioeconomic diversity.

These young people face serious health problems in modern times. More over adolescents girls, in particular are likely to suffer nutritional problems, sexual abuse, violence, rape, unwanted pregnancy, abortion and STDs from which they need protection. There is lack of attention in almost every dimension as adolescent reproductive health. They found poorly informed regarding their own health needs, physical well-being and their own bodies. The knowledge they have is incomplete and many a time confusing. The progress of a country depends on the maximum exploitation of its human resources. The sound health is one of the first requisite conditions of development. Reproductive health of adolescent boys and girls is a key for individual health, family wellbeing and improving their economic productivity (Sridevi, 2012).

Awareness is the state or condition of being aware; or having knowledge and consciousness (http://dictionary.reference.com/browse/awareness, dictionary.com, 2014)

Adolescence is a time of transition and change. It is a period of "physical, cognitive, psychological and moral development that often results in risk-taking behavior." (Cothran and White 2002). The growth of teenagers is rapidly developing. Therefore, this sudden growth spurt is associated with hormonal, cognitive, and emotional changes that make adolescence an especially vulnerable period of life. If teenagers have good nutrition, it will be helpful their physical development and protects them from chronic 
disease (California Nutrition and Physical Activity Guidelines for Adolescents, 2013).

All the adolescents are in need of education, information, counseling and health services with regard to their reproductive health, sexuality and responsible parental hood (Sridevi, 2012). From the time of born until reach 18 years of age the human body weight will increase by 20 times. The muscles will grow bigger and bones will grow longer and stronger. Everything the body needs to power this growth and change can be found in food. Eating a variety of healthy foods will ensure all needs are met (Eat For Health, Australian Dietary Guidelines, 2013).

Adolescence can be divided into three stages. Early adolescence (11-14 years of age) is characterized by the onset of puberty and increased cognitive development. Middle adolescence (15-17 years of age) is characterized by increased independence and experimentation. Late adolescence (18-21 years of age) is a time for making important personal and occupational decisions. Adolescents of both sexes and in all income and racial/ethnic groups are at risk for dietary excesses and deficiencies. Dietary excesses of total fat, saturated fat, cholesterol, sodium, and sugar commonly occur. Most adolescents do not meet dietary recommendations for fruits, vegetables, and calcium-rich foods. Nutrition problems may occur as a result of tobacco and alcohol use, pregnancy, disabilities, or chronic health conditions. (California Nutrition and Physical Activity Guidelines for Adolescents, 2012).

Poor or inappropriate dietary habits increase the risk and/or incidence of chronic disease among adolescents. The pressure to conform to society's view of the ideal body, combined with other factors in an adolescent's life, can set the stage for the development of an eating disorder. Clinical eating disorders or disordered eating habits can affect the teen's ability to learn since the teen spends time thinking about food and weight (Keca, 2004).

During pregnancy, there is a higher need for some vitamins and minerals. These can be obtained through eating healthy foods, such as fruits, vegetables, whole grains, etc. (California Nutrition and Physical Activity Guidelines for Adolescents, Adolescent Nutrition, 2012).

As with many behaviors, healthy eating habits are more likely to take a foothold in adults if they are established at an early age. Yet, at the turn of the $21 \mathrm{st}$ century there were over 155 million overweight children and youth in the world (Lobstein, and Uauy, 2004). Every diet should include proteins, carbohydrates, vitamins, minerals, and fat. During pregnancy, the Dietary reference intakes DRIs are higher for many nutrients. Pregnant women need extra iron and folic acid. To get these extra nutrients, a prenatal vitamin supplement is recommended for most women (The American College of Obstetricians and Gynecologists, 2012).

Adolescent pregnancy is a worldwide concern, According to UNICEF, worldwide every 5th child is born to teenage mother. Worldwide 13 million births each year occur to girls younger than 19 years. The incidence of teenage pregnancies varies dramatically between the different countries. Approximately 90\% of the teenage births occur in developing countries (Teenage Pregnancy, 2014).

Teenage pregnancies are considered problematic because complications from pregnancy and childbirth are the leading causes of death in teenage girls aging between 15 and 19 years in developing countries. It is estimated that 70,000 female teenagers die each year because they are pregnant before they are physically mature enough for successful motherhood (Teenage Pregnancy, 2014).

Significance of the study

A youth age from 10 to 24 percent in Egypt is $28 \%$ of the total population, its equal to 24.1 millions in 2013

(Population Reference Bureau, 2013. The World's Youth Data Sheet, www.prb.org).

Adolescence is the only time following infancy when the rate of physical growth actually increases. This sudden growth spurt is associated with hormonal, cognitive, and emotional changes that make adolescence an especially vulnerable period of life (California Nutrition and Physical Activity Guidelines for Adolescents, 2013).

A large proportion of adolescents in developing countries enters pregnancy with a poor nutritional status and is likely to have suboptimal dietary intake during pregnancy and lactation (King. 2003 and. Pathak et al., 2003). The nutritional status of adolescents is significant for many reasons including the lasting effects of early behavioral patterns. Poor or inappropriate dietary habits increase the risk and/or incidence of chronic disease among adolescents. Of great concern is the increasing rate of obesity and obesity-related health risks, such as diabetes and cardiovascular disease (California Nutrition and Physical Activity Guidelines for Adolescents, 2013). During pregnancy all women need more food, a varied diet, and micronutrient supplements. When energy and other nutrient intake do not increase, the body's own reserves are used, leaving a pregnant woman weakened. Energy needs increase in the second and particularly the third trimester of pregnancy. Inadequate weight gain during pregnancy often results in low birth weight, which increases an infant's risk of dying (USAID, 2004.) 


\section{Aims of the study}

The study was conducted to determine awareness of adolescent females towards basic nutritional needs during pregnancy, through:

- Assessing adolescents' knowledge towards basic nutritional needs during pregnancy.

- Assessing basic needs of nutrition during pregnancy.

\section{Research question}

Is there relation between socio-demographic characteristics of adolescents' girls and their awareness regarding basic nutritional needs during pregnancy?

Research design

A descriptive cross-sectional study was carried out.

\section{Setting}

The study was conducted among two $\mathrm{MCH}$ centers randomly selected from El Minia City $\mathrm{MCH}$ centers. El Minia City is the capital of El Minia governorate, which is one of the Upper Egypt governorates and is located $240 \mathrm{~km}$ south of Cairo. The included centers were selected randomly from the sampling frame of all urban and rural MCH centers in El Minia City. The first center represented the urban area (called theEastern Health Unit) and the second one represented the rural area (called Damaris rural health unit).

\section{Sample}

A convenient sample of 120 adolescent girls who attending MCH centers seeking premarital care or coming with their mothers or sisters who seeking antenatal care or child care. Adolescent girls must be in the age group of 10-19 years and belonging to both rural and urban areas of El- Minia City.

Tools

Interviewing Questionnaire (awareness assessment sheet) was used to collect study data. Interview schedule was prepared both in Minia $\mathrm{MCH}$ and Damaris $\mathrm{MCH}$ to collect relevant data. Instructions were given to them before administrating the tool. Although, the statements were not so difficult to understand, yet necessary assistance was provided to them where need was felt. Interview method was used to collect data from the respondents. All the responses were coded as per coding plan. The sheet contains 47 questions separated into three parts, the first part is about socio-demographic characteristics (10 questions such as age, residence, level of education, marital status, birth order, and mother education), the second part is about adolescent knowledge of nutritional needs during pregnancy (17 questions), data included the importance of iron, folic acid and importance of calcium for pregnant and knowledge about, Primary sources of calcium, iron and folic acid. The third part is about adolescent awareness of basic nutritional needs, and it's importance (20questions), adolescents were asked about their awareness toward basic nutritional needs during pregnancy such as rate of eat legumes (beans lentils - beans - beans - peas - thermos - chickpeas) be more than once week, rate to eat dairy products( milk - yogurt - ripe) be more than once a week, rate eat sugars (biscuits - chocolate - Cake - Nuts - Ice cream - Jam - Honey) be more than once a week. Scoring system of study knowledge tool for each item, a correct response was scored two (2) and the incorrect scored one (1). For each area, the scores of the items were summed up and the total divided by the number of the items, giving a mean score of the part. These scores were converted into a percent score. The total knowledge score was classified as:

- Below 60\% was regarded as unsatisfactory level of knowledge

- $60 \%$ and above was regarded as satisfactory level of knowledge

\section{Scoring system of awareness tool}

A likert scale was used to assess awareness of adolescent regarding basic nutritional needs during pregnancy. The possible responses will be on a four point scale (always - often - some times - never). For each item, the responses always, often, some times and never were respectively scored 4, 3, 2, and 1 . The scoring was reversed for negative statements. The scores of the items were summed up and the total divided by the number of the items, giving a mean score of the part. These scores were converted into a percent score. The total awareness score was classified as:

- Below $60 \%$ was regarded as unaware

- $60 \%$ and above was regarded as aware

Content validity test: to ensure the validity of this tool, it was checked and revised by panel of three experts from nursing staff at Obstetrics and Gynecology Nursing department and Community Health Nursing department, Faculty of Nursing Minia University, whom reviewed the instrument for clarity, relevance, comprehensiveness, and applicability.

\section{Pilot study}

A pilot study was conducted among 20 adolescent girls initially to test the designed questionnaire, consequently some questions were cancelled and some others were re-formed. The aim of this pilot study was to test the clarity of the tools and to estimate the appropriate time required to fill the questionnaire. Based on the result of the pilot study, the necessary modifications in the sheets were done. Those participated in the pilot were excluded from the study. 


\section{Ethical considerations}

Ethical aspect should be considered before starting the study as the following:

- No any harm for participant.

- Maintain confidentiality, esteem \& dignity of subject.

- Freedom to withdraw from participation any time.

- Informed consent should be obtained from the subjects after explanation the purpose of the study

\section{Field work}

The actual fieldwork started from September and ended at the end of November 2013. The questionnaire was taken about 30 minutes to be completed by every adolescent. The researcher attended in the study settings two days per week. The researchers were met with adolescents, explained the purpose of the study, and asked for participation. The researchers started a face to face individual interview with adolescents. Throughout this interview relevant information was recorded in the designed sheet.

\section{Statistical Analysis}

Data were analyzed using SPSS software version 163.0. The $p$-value $<0.05$ was taken as a cutoff for statistical significance and all tests were two-sided. The chi-square test was used for comparison among proportions for qualitative data. Pearson correlation coefficient was used to study the relation between two quantitative variables.

\section{Results}

Table (1) Socio-demographic characteristics of the respondents in the rural and urban residence $($ No $=120)$

\begin{tabular}{|l|c|c|c|c|}
\hline \multirow{2}{*}{} & \multicolumn{3}{|c|}{ Residence (n=120) } \\
\cline { 2 - 5 } & \multicolumn{2}{|c|}{$\begin{array}{c}\text { Rural } \\
\text { (n=53) }\end{array}$} & \multicolumn{2}{c|}{$\begin{array}{c}\text { Urban } \\
\text { (n= 67) }\end{array}$} \\
\cline { 2 - 5 } & No. & \% & No. & \% \\
\hline Age: (years) & & & & \\
\hline $12-$ & 9 & 17.0 & 14 & 20.9 \\
\hline $17-19$ & 44 & 83.0 & 53 & 79.1 \\
\hline Level of education: & 5 & 9.4 & 2 & 3.0 \\
\hline Illiterate & 6 & 11.3 & 14 & 20.9 \\
\hline \begin{tabular}{|} 
Basic \\
education
\end{tabular} & 35 & 66.0 & 30 & 44.8 \\
\hline Secondary & 7 & 13.2 & 21 & 31.3 \\
\hline University & 7 & \multicolumn{5}{|c|}{} \\
\hline Marital status & 47 & 88.7 & 46 & 68.7 \\
\hline Single & 6 & 11.3 & 21 & 31.3 \\
\hline Married & 4 & 7.5 & 11 & 16.4 \\
\hline Pregnancy status & 49 & 92.5 & 10 & 83.6 \\
\hline Pregnant & \multicolumn{5}{|c|}{} \\
\hline Not pregnant & 49 &
\end{tabular}

\begin{tabular}{|c|c|c|c|c|}
\hline & \multicolumn{4}{|c|}{ Residence (n=120) } \\
\hline & \multicolumn{2}{|c|}{$\begin{array}{l}\text { Rural } \\
(n=53)\end{array}$} & \multicolumn{2}{|c|}{$\begin{array}{c}\text { Urban } \\
(n=67)\end{array}$} \\
\hline & No. & $\%$ & No. & $\%$ \\
\hline \multicolumn{5}{|l|}{ Birth order } \\
\hline First & 18 & 34.0 & 17 & 25.4 \\
\hline Second & 12 & 22.6 & 19 & 28.4 \\
\hline Third & 12 & 22.6 & 16 & 23.9 \\
\hline $\begin{array}{l}\text { More than } \\
\text { third }\end{array}$ & 11 & 20.8 & 15 & 22.4 \\
\hline \multicolumn{5}{|c|}{ Father education } \\
\hline Illiterate & 11 & 20.8 & 11 & 16.4 \\
\hline $\begin{array}{l}\text { Basic } \\
\text { education }\end{array}$ & 11 & 20.8 & 11 & 16.4 \\
\hline Secondary & 22 & 41.5 & 16 & 23.9 \\
\hline University & 9 & 17.0 & 29 & 43.3 \\
\hline \multicolumn{5}{|c|}{ Mother education } \\
\hline Illiterate & 19 & 35.8 & 12 & 17.9 \\
\hline $\begin{array}{l}\text { Basic } \\
\text { education }\end{array}$ & 11 & 20.8 & 7 & 10.4 \\
\hline Secondary & 18 & 34.0 & 20 & 29.9 \\
\hline University & 5 & 9.4 & 28 & 41.8 \\
\hline \multicolumn{5}{|c|}{ No. of family members } \\
\hline Three & 5 & 9.4 & 6 & 9.0 \\
\hline Four & 8 & 15.1 & 13 & 19.4 \\
\hline Five of more & 40 & 75.5 & 48 & 71.6 \\
\hline \multicolumn{5}{|l|}{ Family income } \\
\hline Low & 7 & 13.2 & 5 & 7.5 \\
\hline Middle & 41 & 77.4 & 51 & 76.1 \\
\hline High & 5 & 9.4 & 11 & 16.4 \\
\hline
\end{tabular}


Table (2) knowledge of the respondents on the basic nutritional needs during pregnancy and its deficiency (No. $=120$ ).

\begin{tabular}{|c|c|c|c|c|c|}
\hline & \multicolumn{4}{|c|}{ Residence } & \multirow{3}{*}{ P-value } \\
\hline & \multicolumn{2}{|c|}{ Rural (n= 53) } & \multicolumn{2}{|c|}{ Urban $(n=67)$} & \\
\hline & No. & $\%$ & No. & $\%$ & \\
\hline $\begin{array}{l}\text { The essential nutrients are protein, fat, carbohydrates, } \\
\text { minerals, vitamins and water }\end{array}$ & 50 & 94.3 & 62 & 92.5 & 0.980 \\
\hline $\begin{array}{l}\text { Risk of protein deficiency are growth deficiency and } \\
\text { wasting }\end{array}$ & 46 & 86.8 & 56 & 83.6 & 0.625 \\
\hline $\begin{array}{l}\text { Risk of vitamin deficiency are defenselessness bleeding } \\
\text { gums }\end{array}$ & 43 & 81.1 & 53 & 79.1 & 0.783 \\
\hline The risk of iron deficiency is anemia & 42 & 79.2 & 59 & 88.1 & 0.189 \\
\hline Risk of calcium deficiency are rickets and osteomalacia & 48 & 90.6 & 57 & 85.1 & 0.366 \\
\hline Risk of lack of water is dehydration & 49 & 92.5 & 59 & 88.1 & 0.426 \\
\hline $\begin{array}{l}\text { Increase of Carbohydrates intake may lead to increase } \\
\text { the risk of obesity and overweight }\end{array}$ & 48 & 90.6 & 57 & 85.1 & 0.366 \\
\hline $\begin{array}{l}\text { Increase of Fats intake may increase the risk of } \\
\text { atherosclerosis, high blood pressure disease }\end{array}$ & 45 & 84.9 & 57 & 85.1 & 0.979 \\
\hline Pregnant woman need to snack more? & 40 & 75.5 & 56 & 83.6 & 0.270 \\
\hline $\begin{array}{l}\text { Pregnant woman weight increases from } 10 \text { to } 13 \mathrm{~kg} \\
\text { during pregnancy }\end{array}$ & 27 & 50.9 & 53 & 79.1 & $0.001 *$ \\
\hline \multicolumn{5}{|l|}{ Main sources of calcium } & \multirow{7}{*}{0.231} \\
\hline Dairy & 39 & 73.6 & 46 & 68.7 & \\
\hline Meat and fish & 3 & 5.7 & 11 & 16.4 & \\
\hline Beans & 3 & 5.7 & 0 & 0.0 & \\
\hline Fresh fruits and vegetables & 4 & 7.5 & 5 & 7.5 & \\
\hline Nuts & 1 & 1.9 & 1 & 1.5 & \\
\hline Bread, potatoes & 3 & 5.7 & 4 & 6.0 & \\
\hline \multicolumn{5}{|l|}{ Main sources of iron } & \multirow{7}{*}{0.858} \\
\hline Dairy & 2 & 3.8 & 3 & 4.5 & \\
\hline Meat and fish & 8 & 15.1 & 15 & 22.4 & \\
\hline Beans & 6 & 11.3 & 10 & 14.9 & \\
\hline Fresh fruits and vegetables & 33 & 62.3 & 34 & 50.7 & \\
\hline Nuts & 2 & 3.8 & 2 & 3.0 & \\
\hline Bread, potatoes & 2 & 3.8 & 3 & 4.5 & \\
\hline \multicolumn{5}{|l|}{ Primary sources of folic acid } & \multirow{8}{*}{0.054} \\
\hline Dairy & 3 & 5.7 & 3 & 4.5 & \\
\hline Meat and fish & 3 & 5.7 & 6 & 9.0 & \\
\hline Beans & 5 & 9.4 & 19 & 28.4 & \\
\hline Fresh fruits and vegetables & 9 & 17.0 & 5 & 7.5 & \\
\hline Nuts & 4 & 7.5 & 2 & 3.0 & \\
\hline Bread, potatoes & 2 & 3.8 & 7 & 10.4 & \\
\hline There is governing food enough & 27 & 50.9 & 25 & 37.3 & \\
\hline \multicolumn{5}{|l|}{ Nutrients that should be more for pregnant } & \multirow{5}{*}{$0.024 *$} \\
\hline Calcium, iron, and folic acid & 11 & 20.8 & 12 & 17.9 & \\
\hline All of the elements & 9 & 17.0 & 26 & 38.8 & \\
\hline Not more than anything & 33 & 62.3 & 27 & 40.3 & \\
\hline Do not know & 0 & 0.0 & 2 & 3.0 & \\
\hline
\end{tabular}




\begin{tabular}{|c|c|c|c|c|c|}
\hline & \multicolumn{4}{|c|}{ Residence } & \multirow{3}{*}{ P-value } \\
\hline & \multicolumn{2}{|c|}{ Rural $(n=53)$} & \multicolumn{2}{|c|}{ Urban $(n=67)$} & \\
\hline & No. & $\%$ & No. & $\%$ & \\
\hline Importance of calcium for pregnant & & & & & \multirow{5}{*}{0.240} \\
\hline Important for bone formation and growth of the fetus & 4 & 7.5 & 5 & 7.5 & \\
\hline For both mother and child & 14 & 26.4 & 28 & 41.8 & \\
\hline Not important at all & 34 & 64.2 & 34 & 50.7 & \\
\hline Do not know & 1 & 1.9 & 0 & 0.0 & \\
\hline \multicolumn{5}{|l|}{ Importance of iron for pregnant } & \multirow{5}{*}{0.127} \\
\hline Protects the mother of anemia & 11 & 20.8 & 6 & 9.0 & \\
\hline Protect a child from anemia & 23 & 43.4 & 42 & 62.7 & \\
\hline Not important at all & 16 & 30.2 & 17 & 25.4 & \\
\hline Do not know & 3 & 5.7 & 2 & 3.0 & \\
\hline \multicolumn{5}{|l|}{ Importance of folic acid component for pregnant } & \multirow{5}{*}{$0.021 *$} \\
\hline The formation of the fetus Skelton & 25 & 47.2 & 19 & 28.4 & \\
\hline $\begin{array}{l}\text { Is not configured for genetic defects and } \\
\text { malformations (cleft lip - holes in the heart) }\end{array}$ & 7 & 13.2 & 5 & 7.5 & \\
\hline Not important at all & 13 & 24.5 & 35 & 52.2 & \\
\hline Do not know & 8 & 15.1 & 8 & 11.9 & \\
\hline
\end{tabular}

* Statistical significant difference $(P<0.05)$

Table (3) Relation of the Knowledge and the awareness of study respond.

\begin{tabular}{|c|c|c|c|c|c|}
\hline & \multicolumn{4}{|c|}{ Residence } & \multirow{3}{*}{ P-value } \\
\hline & \multicolumn{2}{|c|}{ Rural $(n=53)$} & \multicolumn{2}{|c|}{ Urban $(n=67)$} & \\
\hline & No. & $\%$ & No. & $\%$ & \\
\hline \multicolumn{5}{|c|}{ Level of knowledge } & \multirow{3}{*}{0.249} \\
\hline Satisfactory & 31 & 40.3 & 46 & 59.7 & \\
\hline Unsatisfactory & 22 & 51.2 & 21 & 48.8 & \\
\hline \multicolumn{5}{|c|}{ Level of awareness } & \multirow{3}{*}{0.664} \\
\hline Aware & 41 & 43.2 & 54 & 56.8 & \\
\hline Not aware & 12 & 48.0 & 13 & 52.0 & \\
\hline
\end{tabular}

Table (4) Relation of the Level of Knowledge and socio-demographic characteristics

\begin{tabular}{|c|c|c|c|c|c|}
\hline & \multicolumn{4}{|c|}{ Level of knowledge } & \multirow{3}{*}{ P-value } \\
\hline & \multicolumn{2}{|c|}{ Unsatisfactory $(n=43)$} & \multicolumn{2}{|c|}{ Satisfactory $(n=77)$} & \\
\hline & No. & $\%$ & No. & $\%$ & \\
\hline \multicolumn{5}{|l|}{ Age: (years) } & \multirow{3}{*}{$0.021 *$} \\
\hline $12-16$ & 13 & 56.5 & 10 & 43.5 & \\
\hline $17-19$ & 30 & 30.9 & 67 & 69.1 & \\
\hline \multicolumn{5}{|l|}{ Level of education } & \multirow{5}{*}{$0.001 * *$} \\
\hline Illiterate & 7 & 100.0 & 0 & 0.0 & \\
\hline Basic education & 10 & 50.0 & 10 & 50.0 & \\
\hline Secondary & 20 & 30.8 & 45 & 69.2 & \\
\hline University & 6 & 21.4 & 22 & 78.6 & \\
\hline
\end{tabular}




\begin{tabular}{|c|c|c|c|c|c|}
\hline & \multicolumn{4}{|c|}{ Level of knowledge } & \multirow{3}{*}{ P-value } \\
\hline & \multicolumn{2}{|c|}{ Unsatisfactory $(n=43)$} & \multicolumn{2}{|c|}{ Satisfactory $(n=77)$} & \\
\hline & No. & $\%$ & No. & $\%$ & \\
\hline \multicolumn{5}{|l|}{ Marital status } & \multirow{3}{*}{0.130} \\
\hline Single & 30 & 32.3 & 63 & 67.7 & \\
\hline Married & 13 & 48.1 & 14 & 51.9 & \\
\hline \multicolumn{5}{|l|}{ Birth order } & \multirow{5}{*}{$0.013 *$} \\
\hline First & 12 & 34.3 & 23 & 65.7 & \\
\hline Second & 8 & 25.8 & 23 & 74.2 & \\
\hline Third & 17 & 60.7 & 11 & 39.3 & \\
\hline More than third & 6 & 23.1 & 20 & 76.9 & \\
\hline \multicolumn{5}{|l|}{ Father education } & \multirow{5}{*}{0.054} \\
\hline Illiterate & 8 & 36.4 & 14 & 63.6 & \\
\hline Basic education & 13 & 59.1 & 9 & 40.9 & \\
\hline Secondary & 13 & 34.2 & 25 & 65.8 & \\
\hline University & 9 & 23.7 & 29 & 76.3 & \\
\hline \multicolumn{5}{|l|}{ Mother education } & \multirow{5}{*}{$0.008 *$} \\
\hline Illiterate & 11 & 35.5 & 20 & 64.5 & \\
\hline Basic education & 11 & 61.1 & 7 & 38.9 & \\
\hline Secondary & 16 & 42.1 & 22 & 57.9 & \\
\hline University & 5 & 15.2 & 28 & 84.8 & \\
\hline \multicolumn{5}{|c|}{ No. of family members } & \multirow{4}{*}{$0.001 * *$} \\
\hline Three & 9 & 81.8 & 2 & 18.2 & \\
\hline Four & 10 & 47.6 & 11 & 52.4 & \\
\hline Five or more & 24 & 27.3 & 64 & 72.7 & \\
\hline
\end{tabular}

* Statistical significant difference $(P<0.05) \quad * *$ Highly statistical significant difference $(p<0.001)$

Table (5) Relationship of the Level of Awareness and socio-demographic characteristics

\begin{tabular}{|c|c|c|c|c|c|}
\hline & \multicolumn{4}{|c|}{ Level of awareness } & \multirow{3}{*}{ P. value } \\
\hline & \multicolumn{2}{|c|}{ Not aware } & \multicolumn{2}{|c|}{ Aware } & \\
\hline & No. & $\%$ & No. & $\%$ & \\
\hline \multicolumn{5}{|l|}{ Age: (years) } & \multirow{3}{*}{$<0.001 * *$} \\
\hline $10-15$ & 12 & 52.2 & 11 & 47.8 & \\
\hline $15-19$ & 13 & 13.4 & 84 & 86.6 & \\
\hline \multicolumn{5}{|l|}{ Level of education } & \multirow{5}{*}{$<0.001 * *$} \\
\hline Illiterate & 6 & 85.7 & 1 & 14.3 & \\
\hline Basic education & 12 & 60.0 & 8 & 40.0 & \\
\hline Secondary & 5 & 7.7 & 60 & 92.3 & \\
\hline University & 2 & 7.1 & 26 & 92.9 & \\
\hline \multicolumn{5}{|l|}{ Marital status } & \multirow{3}{*}{0.737} \\
\hline Single & 20 & 21.5 & 73 & 78.5 & \\
\hline Married & 5 & 18.5 & 22 & 81.5 & \\
\hline \multicolumn{5}{|l|}{ Birth order } & \multirow{5}{*}{0.203} \\
\hline First & 7 & 20.0 & 28 & 80.0 & \\
\hline Second & 3 & 9.7 & 28 & 90.3 & \\
\hline Third & 9 & 32.1 & 19 & 67.9 & \\
\hline More than third & 6 & 23.1 & 20 & 76.9 & \\
\hline
\end{tabular}




\begin{tabular}{|c|c|c|c|c|c|}
\hline & \multicolumn{4}{|c|}{ Level of awareness } & \multirow{3}{*}{ P. value } \\
\hline & \multicolumn{2}{|c|}{ Not aware } & \multicolumn{2}{|c|}{ Aware } & \\
\hline & No. & $\%$ & No. & $\%$ & \\
\hline \multicolumn{5}{|l|}{ Father education } & \multirow{5}{*}{0.854} \\
\hline Illiterate & 6 & 27.3 & 16 & 72.7 & \\
\hline Basic education & 4 & 18.2 & 18 & 81.8 & \\
\hline Secondary & 8 & 21.1 & 30 & 78.9 & \\
\hline University & 7 & 18.4 & 31 & 81.6 & \\
\hline \multicolumn{5}{|c|}{ Mother education: } & \multirow{5}{*}{0.568} \\
\hline Illiterate & 6 & 19.4 & 25 & 80.6 & \\
\hline Basic education & 6 & 33.3 & 12 & 66.7 & \\
\hline Secondary & 7 & 18.4 & 31 & 81.6 & \\
\hline University & 6 & 18.2 & 27 & 81.8 & \\
\hline \multicolumn{5}{|c|}{ No. of family embers } & \multirow{4}{*}{0.220} \\
\hline Three & 3 & 27.3 & 8 & 72.7 & \\
\hline Four & 7 & 33.3 & 14 & 66.7 & \\
\hline Five or more & 15 & 17.0 & 73 & 83.0 & \\
\hline
\end{tabular}

** Highly statistical significant difference $(p<0.001)$

Figure (1): Correlation between score of knowledge and awareness

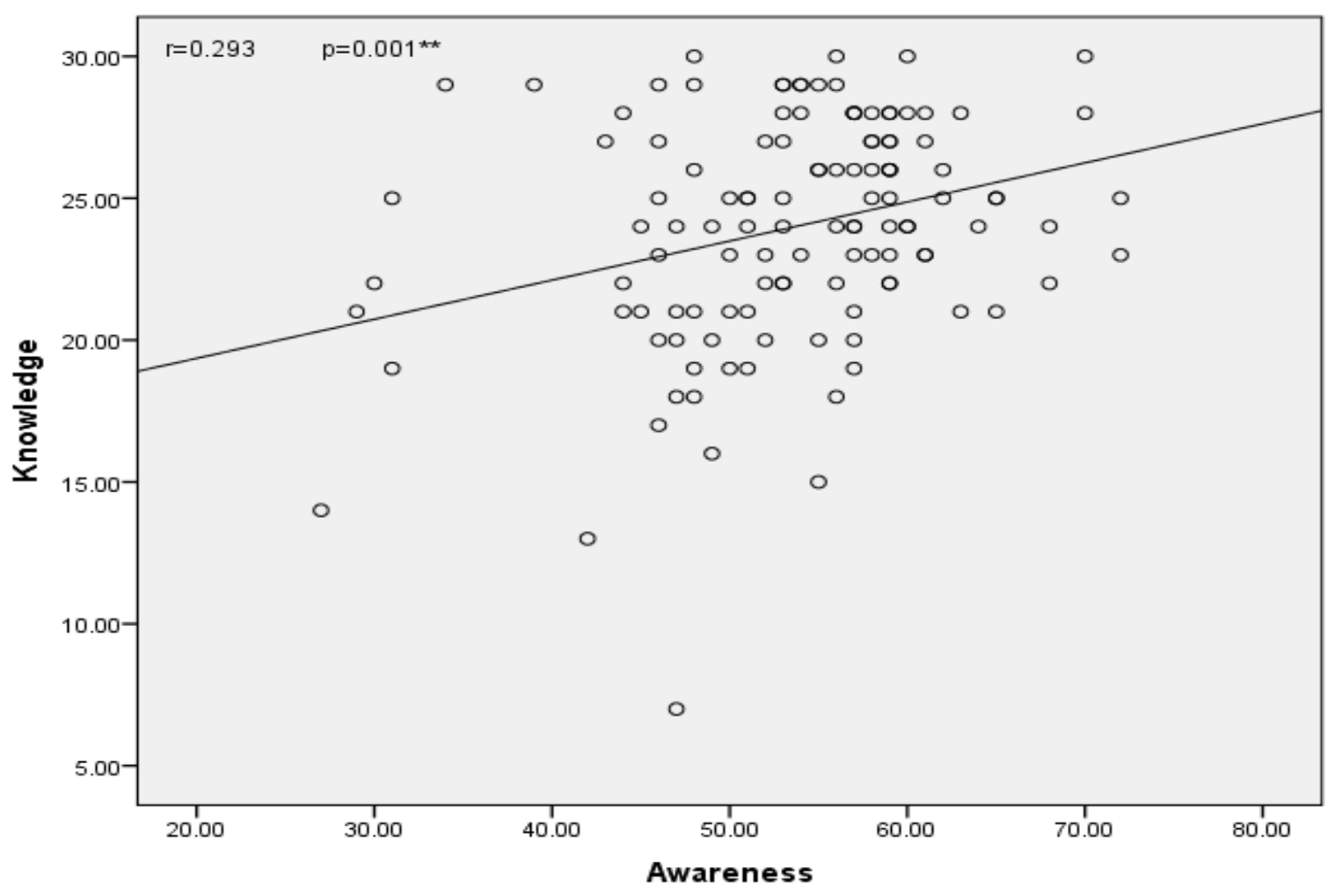


Table (1) : show that both in the rural and urban areas, most of the respondents are aged 17 to 19 years old, are in the secondary level, single, non-pregnant, and belong to a middle-income family composed of five or more members. With regard to birth order, the sample was well selected from the different birth orders. With regard to the respondents' father educational attainment, there 11 illiterate both in the rural and urban areas. However, thirty-one or $58.5 \%$ of the fathers of those from the rural areas while 45 or $67.2 \%$ of the fathers of those from the urban areas have finished at least a secondary level. With regard to the respondents' mother educational attainment, there are 19 mothers and 12 mothers who are illiterates from the rural and urban areas, respectively. Twenty-three or $43.4 \%$ and 48 or $71.7 \%$ of the mothers have finished secondary in the rural and urban areas, respectively.

Table (2) : showed that $(94.3 \%, 86.8 \%, 81.1 \%, 79.2$, $90.6 \%, 90.6 \%, 92.5 \%, 84.9 \%)$ of rural responds had good knowledge about essential nutrients during pregnancy and deficiency of protein, vitamins, iron, calcium, increase of carbohydrates and increase of fats respectively While, $79.1 \%$ of urban responds had good knowledge about the pregnant woman weight increase from 10 to $13 \mathrm{~kg}$ during pregnancy. Also, this table revealed that there is a significant difference on the level of knowledge of the respondents from the rural and urban areas regarding to weight gain during pregnancy. Also Table (2) illustrated that 73.6 and $68.7 \%$ respectively of rural and urban responds had satisfactory knowledge about main sources of calcium, $62.3 \%$ and $50.7 \%$ of rural and urban responds had satisfactory knowledge about main sources of iron. $40.3 \%$ of rural responds knew that women nutrition during pregnancy should not differ than that for other women, while $62.3 \%$ of urban responds knew that women nutrition during pregnancy should not differ than that for other women. Regarding to the importance of calcium, $64.2 \%$ and $50.7 \%$ respectively of rural and urban responds knew that calcium is not important at all. Concerning to importance of iron, $43.4 \%$ and $62.7 \%$ respectively of rural and urban responds reported that iron protect child from anemia. With regard the importance of folic acid, $47.2 \%$ of rural responds knew that folic acid is important for formation of the fetus while, $52.2 \%$ of urban responds knew that folic acid is not important at all. Also this table above shows that there is a significant difference on the level of knowledge of the respondents from the rural and urban areas with regards on the following items: the nutrients that should be more of them for pregnant, and the importance of folic acid component for pregnant.
Table (3) : illustrated that $51.2 \%$ and $48.8 \%$ respectively of rural and urban responds had unsatisfactory level of knowledge about basic nutritional needs during pregnancy. Also this table shows that there is no significant difference between the respondents' level of knowledge and type of residence, $\mathrm{p}=0.249$. Also this table shows that $43.2 \%$ and $56.8 \%$ respectively of rural and urban responds were unaware about basic nutritional needs during pregnancy. It also shows that there is no significant difference between the respondents' level of awareness and type of residence, $p=0.664$ which is greater than 0.05 .

Table (4) : reveled that there is a significant relationship between the level of knowledge and the following variables: age, level of education, birth order, and mother's educational attainment. Respondents aged 17-19 have satisfactory level of knowledge while those aged 12-16 have unsatisfactory level of knowledge. This implies that the older the respondents were, more knowledgeable about basic nutritional needs during pregnancy. Illiterate and those respondents who reached only up to basic education have unsatisfactory level of knowledge and those who went to secondary and university level have satisfactory level of knowledge. This implies that the higher the educational attainment a respondent has, the more satisfactory his/her level of knowledge is. It also means that educational attainment is a factor to have satisfactory level of knowledge. With regards to birth order, those born as third children have unsatisfactory level of knowledge while those born as the first, second, and more than third children have satisfactory level of knowledge. Mother's educational attainment also affects the level of knowledge of the respondents. This means that educated mothers have contributed much to their daughter's higher level of knowledge.

Table (5) shows that there is significant relationship between the level of awareness and the different variables: age, level of education. Respondents aged 17-19 were aware about basic nutritional needs during pregnancy while those aged 12-16 were not aware. Most of illiterate responds and those who reached only up to basic education were not aware about basic nutritional needs during pregnancy and most of those who went to secondary and university level were aware about basic nutritional needs during pregnancy.

Figure (1) : shows that there is moderate correlation and highly significant between level of knowledge and level of awareness of the respondents about nutrition during pregnancy, $r=0.293$ and $p=0.001$ 


\section{Discussion}

The nutritional status of the expectant mother is the most important determinant of pregnancy outcomes, including the birth weight of the newborn (Dharmalingam et al., 2010). Young age is the period wherein girls need special care particularly in shaping their health \& well being. They need to be well informed about each and every aspect of health $\&$ other related areas including nutrition (Harshad et al., 2013). Low maternal weight before pregnancy and inadequate weight gain and calories by the expectant mother are all associated with the delivery of low birth weight infants. (Guyton \& Hall 2006). stated that optimum nutrition could not eliminate all problems that might arise in pregnancy, but it established a good foundation for supporting needs of mother and fetus. Because of the importance of maternal nutritional status and its great effect on both mother and fetal health, the present study was undertaken to determine awareness level of adolescents towards basic nutritional needs during pregnancy.

The present study revealed that most of the respondents aged 17 to 19 years old, their educational level was secondary level, they was single, non-pregnant, and belong to a middle-income and their family composed of five or more members. These findings are in agreement with the study by (Sharma et al., 2009). Moreover, (Perry \& Lowder 2006). stated that inadequate maternal education in developing countries was considered as a problem and it placed as a serious handicap in dissimulating information and new ideas.

The present study also revealed that more than half of rural responds had unsatisfactory level of knowledge about basic nutritional needs during pregnancy (regarding the meaning, and the importance, a well balanced diet for the pregnant women). They also didn't know exactly the importance of different food elements, and their sources such as (calcium \&iron and folic acid). This finding is in accordance with (Neeson et al., 2002 and Latifa et al., 2012) who reported that urban women had higher mean of nutritional knowledge and practices compared to women in rural area. This can be attributed to the fact that adolescents lack better access to information about nutrition during pregnancy because they are single and their curriculum wasn't contain subjects related to nutritional during pregnancy. However, if mother appreciated the importance of good nutrition during pregnancy, she will plan her diet properly, which will reflected on her pregnancy outcome (WHO, 2006). Also the present study revealed that urban responds were unaware about nutritional needs during pregnancy compared to adolescents in rural area. This finding is in line with (Seema et al., 2010). who concluded that majority of adolescent girls were not aware about their nutritional needs, ignorance about micronutrients and protective foods prevailed in adolescent girls

The present study also revealed that respondents aged 12-16 have unsatisfactory level of knowledge and not aware about basic nutritional needs during pregnancy. This implies that the older respondents were, more knowledgeable and aware about basic nutritional needs during pregnancy. Illiterate and those respondents who reached only up to basic education have unsatisfactory level of knowledge and not aware and those who went to secondary and university level have satisfactory level of knowledge and aware. This results is supported by (Latifa et al., 2012 and Sharma et al., 2009). who reported that most women aged 25-35 years had higher of nutritional knowledge, compared to those younger than 25 years and above 35 . Women with high level of education had high nutritional knowledge compared to those had low and moderate education. It also means that educational attainment is a factor to have satisfactory level of knowledge. With regards to birth order, those born as third children have unsatisfactory level of knowledge while those born as the first, second, and more than third children have satisfactory level of knowledge. Mother's educational attainment also affects the level of knowledge of the respondents. This means that educated mothers have contributed much to their daughter's higher level of knowledge.

The findings of this study also illustrated that there is moderate correlation and highly significant between level of knowledge and level of awareness of the respondents about nutrition during pregnancy. This finding is in accordance with Blount, 2006 who reported that adolescent females were more likely to deliver lower birth weight infant than do women in their twenties and/or thirties.

\section{Conclusions}

Based on the results of the present study and research questions, it was concluded that a significant relationship between the level of knowledge and the following socio-demographic characteristics: age, level of education, birth order, and mother's educational attainment, also there is significant relationship between the level of awareness and the following socio-demographic characteristics: age, level of education.

This study also revealed that $(51.2 \%$ and $48.8 \%$ respectively) of rural and urban responds had unsatisfactory level of knowledge about basic 
nutritional needs during pregnancy (regarding the meaning, and the importance, a well balanced diet for the pregnant women). They also didn't know exactly the importance of different food elements, and their sources such as (calcium \&iron and folic acid). Also the present study revealed that $(48.0 \%$ and $52.0 \%$ respectively) of rural and urban responds were not aware about nutrition during pregnancy. There is a significant relationship between the level of knowledge and awareness level among the following variables: age, level of education, and mother's educational attainment. Older the respondents are more knowledgeable than those younger ones on the basic nutritional needs dpuring pregnancy. Respondents with higher the educational attainment have higher level of knowledge. It also means that educational attainment is a factor to have satisfactory level of knowledge. Mother's educational attainment also affects the level of knowledge of the respondents. Also, there is moderate correlation and highly significant between level of knowledge and level of awareness of the respondents about nutrition during pregnancy.

\section{Recommendations}

In the light of the findings of the present study, the following recommendations are suggested:

- The school education program for school girls about dietary education and nutritional needs at this age can improve the overall health and nutritional knowledge and status of adolescents.

- There is need and scope for designing and implementing adolescent nutrition education program.

- Mass media campaigns often targeted basic nutritional needs during pregnancy.

\section{References}

1. A manifesto for the world we want. Lancet (2012) : 380(9857), p. 1881.

2. Blount, D., (2006) : American pregnancy association, promoting pregnancy wellness. Nutrition for Pregnant Women. Retrieved July, from http://scc.uchicago.edu/nutritionpregant.htm.

3. California Nutrition and Physical Activity Guidelines for Adolescents, (2012) : Adolescent Nutrition.

4. California Nutrition and Physical Activity Guidelines for Adolescents, (2013) : $\mathrm{CDPH}$ Grant through the Maternal, Child and Adolescent Health Division, Center for Family Health.
5. California Nutrition and Physical Activity Guidelines for Adolescents, (2013).

6. Cothran M., \& White J., (2002) : Adolescent behavior and sexually transmitted diseases: the dilemma of human papillomavirus. Health Care Women Int.; 23(3): Pp306-19.

7. Delisle H., La sécurité alimentaire, ses liens avec la nutrition et la santé. In: Delisle $H$, Shaw D., (Eds). The Quest for Food Security in the Twenty First Century. Can J Development Studies (1998) : a; 19 (Special Issue): pp307-21

8. Dharmalingam A., Navanetham K., KrishnaKumar C., (2010) : Nutritional status of mothers and low birth weight in India. Maternal Child Health J; 14: Pp 290-298.

9. Eat for health, Australian Dietary Guidelines. Dietary Guidelines for Children and Adolescents in Australia, (2013).

10. Gerrard, M., Gibbons, F., Reis-Bergan, M., Trudeau, L., Vande Lune, L., \& Buunk, B., (2002) : Inhibitory effects of drinker and nondrinker prototypes on adolescent alcohol consumption. Health Psychology, 21, 601-609.

11. Guyton, A., Hall, J., (2006) : Textbook of Medical Physiology. $11^{\text {th }}$ ed. Elselvier Inc. Philadelphia pp 212-220.

12. Harshad Patel, Harsha Solanki, Vibha Gosalia, Falguni Vora, M., Singh (2013) : A., study of awareness of nutrition and anemia among college going students of Mahila college of Bhavnagare. National Journal of Community Medicine Volume 4|Issue 2|Apr - June, pp. 330-303.

13. http://dictionary.reference.com/browse/aware ness, dictionary.com,( 2014).

14. Keca, J., (2004) : National Association of School Psychologists, 4340 East West Highway, Suite 402, Bethesda, MD 20814(301) Pp 6570270 .

15. King J., (2003): the risk of maternal nutritional depletion and poor outcomes increases in early and closely spaced pregnancies. J Nutr. 133: S1732-6.

16. Latifa M., Fouda1, Manal H., Ahmed 2 \& Nihal S., Shehab3 (2012) : Nutritional Awareness of Women during Pregnancy. Journal of American $\quad$ Science, http://www.americanscience.org.

17. Lobstein, T., Baur, L., and Uauy, R., (2004): "Obesity in children and young people: A crisis in public health", Obesity Reviews, Vol. 5 No. 1, pp. 4-85.

18. Machel J., Unsafe sexual behaviour among schoolgirls in Mozambique: a matter of 
gender and class. Reprod Health Matters (2001) : 9(17): pp. 82-90.

19. Malamitsi-Puchner A., Boutsikou T., Adolescent pregnancy and perinatal outcome. Pediatr Endocrinol Rev. (2006) :3 Suppl 1: pp. 170-1. 3.

20. Neeson N., Stanhope M., Lancaster J., (2002) Foundations of community health nursing, community oriented practice .2nd.London: Mosby Company; pp. 355-63.

21. Pathak P., Singh P., Kapil U., Raghuvanshi R., (2003) : Prevalence of iron, vitamin A, and iodine deficiencies amongst adolescent pregnant mothers. Indian J Pediatr. 70: pp. 299-301.

22. Perry P., Lowder milk D., (2006) : Maternity Nursing, ${ }^{\text {th }}$ ed, Mosby; 221.

23. Population Reference Bureau, (2013) : The World's Youth Data Sheet Www.Prb.Org

24. Rogol A., Clark P., Roemmich J., Growth and pubertal development in children and adolescents: effects of diet and physical activity. Am J., Clin Nutr. (2000) : pp. 72:S521-8.

25. Seema C., Mishra C., \& Shukla K., (2010): Dietary pattern and nutrition related knowledge of rural adolescent girls. Indian J. Prev. Soc. Med Vol. 41 No.3 \& 4.pp.207-214

26. Sharma S., Nagar S., and Chopra G., (2009): Health Awareness of Rural Adolescent Girls: An Intervention Study. J Soc Sci, 21(2): pp. 99-104.

27. Sheloj M., Joshi, Swarna Likhar, Sanjay S., Agarwal \& Umashankar, Shukla (2014): A., study of nutritional status of adolescent girls in rural area of Bhopal district. National Journal of Community Medicine Volume 5 | Issue 2|Apr June pp.

28. Spear B., Adolescent growth \& development. J Am Diet Assoc. (2002) : 102:S pp 23-9.

29. Sridevi, K., (2012). Awareness towards adolescent reproductive health among teacher trainees of awassa, south ethiopia.: Review of Research. Vol. (1) Issue.VIII/May; 12, pp.1-4.

30. Stewart C., Katz J., Khatry S., LeClerq S., Shrestha S., West K., Christian P., Preterm delivery but not intrauterine growth retardation is associated with young maternal age among primiparae in rural Nepal. Matern Child Nutr. (2007): (3) pp 174-85.

31. Teenage Pregnancy - Its Impact on Maternal and Fetal Outcome, International Journal of Scientific Study | March (2014) | Vol 1 | Issue 6.

32. Teenage Pregnancy - Its Impact on Maternal and Fetal Outcome, International Journal of Scientific Study | March (2014) | Vol (1) Issue 6.2014
33. The American College of Obstetricians and Gynecologists (ACOG). (2012) : Nutrition during pregnancy.

34. United Nations Children's Fund (UNICEF). Towards an AIDS-free Generation - Children and AIDS: Sixth Stocktaking Report, (2013) : New York, NY: UNICEF, p ii).

35. United Nations, Department of Economic and Social Affairs, Population Division, World Population Prospects: (2008) : Revision, <www.esa.un.org/unpd/wpp2008/index.htm>, accessed October 2010).

36. USAID (2004) : Maternal Nutrition: Issues and Interventions. Updated 2004.

37. Williams, P., Holmbeck, G., \& Greenley, R., (2002) : Adolescent health psychology. Journal of Consulting and Clinical Psychology, 70, pp. 828-842.

38. World Health Organization, (2006) : Promoting Optimal Fetal Development: report of a technical consultation. [Cited 2010, May 2]. Available from: http://www.who.int/nutrition/publications/fetal_d ev_repo rt_EN.pdf. 